\title{
Job Rotation Practices and Employees Performance: Do Job Satisfaction and Organizational Commitment Matter?
}

\author{
Abdul-Razak Suleman (D) ${ }^{1}{ }^{1}$, Bernard Bekuni Boawei Bingab ${ }^{2}$, Kwame Owusu Boakye ${ }^{3}$, Richard \\ Sam-Mensah (D) 4
}

University of Ghana Business School, Department of Organisation and Human Resource Management, Legon-Accra, Ghana ${ }^{1}$ University of Education, Department of Management Sciences, Winneba, Ghana 2,3 \&4

\section{ABSTRACT}

Purpose: This study sought to propose and test a model that examines the mediating roles of job satisfaction and organizational commitment in the nexus between job rotation practices and employee performance.

Design: The study adopted a cross-sectional survey approach and obtained data through questionnaires from 122 administrative staff of the University of Education, Winneba. The Partial Least Squares, Structural Equation Modelling (PLS-SEM) approach was used to test the study's proposed model.

Findings: The results supported the proposed model, showing that organizational commitment and job satisfaction are partial mediators in the relationship between job rotation practices and employees' performance.

Policy Implication: The findings suggest that management must ensure that employees are satisfied and committed to the job rotation practices in order to enhance their performance. Thus, job rotation practices must provide the climate that encourages career growth and development and fosters creativity in employees and not just as a routine practice or a means of punishment.

Originality: The study brings to bear the extent to which job rotation practices predict employee performance in a Sub-Saharan African Country and the indirect effects of job satisfaction and organizational commitment in this relationship.

\section{ARTICLE INFO}

Received: November 04, 2021

Revised: January 19, 2022

Accepted: January 20, 2022

Published: January 23, 2022

Keywords:

Job Rotation Practices

Job Satisfaction

Organizational Commitment

Employees Performance

(cc) BY (C) 2022 The Author(s)

$\triangle$ Corresponding author: abdulrazaksuleman10@gmail.com

\section{Introduction}

Job rotation has been noted to be one of the most critical issues in Human Resource Management since human resource effectiveness depends on the growth of an individual's job according to their potential and traits (Zin et al., 2021). Job consistency and employees performing repetitive tasks do not warrant the required efficiency and effectiveness in today's fast-paced technological environment (Akhbari \& Zargarani, 2011). As 
such, businesses, both small and large, whether private or public, strive towards improving work design systems by developing job rotation strategies to enhance employees' performance (Fernando \& Dissanayake, 2019).

In the twenty-first century, organizations are confronted with swift changes in the external environment, which affect their internal operation (Harvey et al., 2013). For instance, stakeholders, including customers, skilled workers, regulators, social activists, and shareholders, increasingly pressure businesses to achieve exceptional results while meeting their diverse needs (Nyuur et al., 2016). Scholars (e.g., Akhbari \& Zargarani, 2011; Mohsan et al., 2012) have long recognized that job rotation is an effective strategy for achieving compelling performances in organizations. According to Mohsan et al. (2012), having a mechanism like job rotation to affect employees' performance and improve their commitment to their work is one way to increase employee motivation. As a result, it is suggested that job rotation is not only a desirable but also an unavoidable need (Sanséau \& Opoku, 2019), as it is seen as a promising method for organizations to develop their employees, managers, and executives holistically (Mohsan et al., 2012).

Despite the increasing effects of job rotation on employee and organizational outcomes, there is still limited literature on job rotation issues (Jocom et al., 2017; Zin et al., 2021) in developing countries such as Ghana (Nyuur et al., 2016) and employee's performance in the education sector (Ajusa \& Atambo, 2016). Furthermore, the extant literature on job rotation and employees' performance (e.g., Oparanman \& Nwaeke, 2015; Ajusa \& Atambo, 2016) has generally focused on manufacturing firms' studies where performance can easily be measured using productivity or efficiency in terms of the input-output relationship. Arasanmi and Krishna (2019) observed that organizational commitment mediates the relationships between employer branding, job designs, and employee performance. Also, Thongpapanl et al. (2018) reported that job rotation indirectly affects employee performance through job satisfaction in the Canadian manufacturing industry. Still, the case may be different in other contexts. Yet, again, Ajusa and Atambo (2016) argue that job rotation, despite its impacts, is one of the least studied research issues in contemporary times, especially in universities. Therefore, this study seeks to examine the mediating effects of job satisfaction and organizational commitment in predicting employees' performance by job rotation at the University of Education, Winneba (UEW).

\section{Literature Review}

\section{The Herzberg Two-Factor Theory}

Psychologist Frederick Herzberg (1966) explored the question, "what do people want from their jobs?" In examining the question, he came up with some elements that contribute to extreme satisfaction and unhappiness. These factors include the job itself, achievement, recognition, advancement, and responsibility. Herzberg et al. (1959) argued that two general independent types of factors affect job satisfaction and job dissatisfaction in the formative stages of the Two-Factor Theory. These are intrinsic factors that they also referred to as "motivators" and the extrinsic factors they refer to as "Hygiene or Dissatisfiers". According to them, motivators stimulate workers to perform better, resulting in job satisfaction. Thus, when these motivators are present at the workplace, employees' sense of satisfaction from their job is triggered, enhancing their commitment towards the organization.

On the other hand, they argued that the dissatisfiers lessen or eliminate job satisfaction. These factors, they believe, may not always inspire employees, and their absence could indicate job dissatisfaction. Some examples include salary, supervision, interpersonal relationships, working conditions, organizational policy and management, the supervisor's management style, and job security. Therefore, this study identified employees' satisfaction and commitment when transferred from one job to another or one position and how job rotation practice impacts employees' performance. Organizational commitment represents the psychological bond that ties a person to an organization. This psychological relation is expressed in various dimensions: affective, continuance, and normative commitment (Allen \& Meyer, 1996). The first dimension is emotional attachments attributable. Employees who are emotionally resilient towards their organizations work much harder and 
achieve better results than those who exhibit continuance commitment (Fried \& Langer, 2020). These are workers who continue to work for an organization - with a deep affective passion - for the purpose that they actually want to. As a result, their organizations are likely to benefit more because of reduced absenteeism and organizational citizenship behaviors (Allen \& Meyer, 1996; Lambert et al., 2020; Thakur et al., 2020).

Continuance commitment as the second dimension can be attributed to financial gains or the fear of loss. Thus, employees weigh the merits and demerits of leaving their current organization and decide whether to stay or leave. When they perceive that the merits associated with their current organization exceed that of elsewhere, their commitment to the organization in question is strengthened (Mangundjaya \& Farahzehan, 2019). The merits come in monetary compensation, social networks, and job-related competencies over time (Lambert et al., 2020; Redditt et al., 2019). According to Shujaat et al. (2019), continuance commitment increases with experience and age; hence employees who work in an organization that offers them stable positions with high chances of career development are more likely to develop continuance commitment towards the said organization. Obligatory feelings account for the final dimension. Employees that are resilient in the context of normative commitment are highly loyal regardless of the situations at work. This is because they owe allegiance to employers and are less likely to quit or be absent and are willing to embrace and commit to any change made at their workplace (Allen \& Meyer, 1996; Mangundjaya \& Farahzehan, 2019). In the specific context of this study, one of the critical issues investigated is the extent to which the job rotation practices (which largely falls under the motivators as explained above) predict employees' performance (i.e., directly) and through job satisfaction and organizational commitment (i.e., indirectly).

\section{Job Rotation Practices}

Mohan and Gomathi (2015) defined job rotation practices as the activities that involve mobilizing employees across functional departments in an organization. Job rotation practices, usually shortened as job rotation, are distinguished from job promotion. From a broader perspective, the employees augment their understanding and share practices between functions under job rotation, but promotion generally comes with an increase in remuneration and working conditions (Sebt et al., 2021). According to Arasanmi and Krishna (2019), job rotation also enhances employees' learning and skill acquisition and allows them better to understand the capabilities and challenges of other departments. As a factor of organizational climate, job rotation encourages information exchange and is conducive for cross-functional trust (Thongpapanl et al., 2018). Thus, job rotation can assist in developing a deeper and broader understanding of another functional department. This is achieved as the rotating employee becomes privy to the other department's "thought-world" and knowledge domain during the time of rotation within the other function. However, job rotation has some adverse effects on organizational outcomes, especially when the employees are hesitant to move (Fernando \& Dissanayake, 2019).

\section{Job Satisfaction}

Job satisfaction has been defined in a variety of ways. For instance, Locke (1976) defined job satisfaction as a pleasurable or positive emotional state resulting from the appraisal of one's job and job experience. Thus, it is the positive feelings about one's job, the influence that emanates from it, and the understanding that the job provides what they value. Recently, Cansoy (2019) defined job satisfaction as a measure of the feeling towards the work of a specific person. According to Dilig-Ruiz et al. (2018), job satisfaction is more related to an organization's approach to improving job design and work-life quality, among other factors. Halcomb et al. (2018) added that it is imperative to measure job satisfaction positively related to performance. Therefore, forward-looking organizations need to ensure their employees are satisfied with their working conditions and arrangements. 


\section{Organizational Commitment}

Ho et al. (2009) defined organizational commitment as employees' emotional attachment and psychological bond with an organization. Thus, it indicates an employee's willingness to remain a member of an organization. According to Lambert et al. (2020), a committed employee exhibits psychological loyalty to work and identifies with the organization's goals. Research suggests that employees with strong organizational commitment are valuable assets of an organization; as a committed workforce, they can improve organizational performance and increase productivity and competitiveness (Mohsan et al., 2012; Redditt et al., 2019; Rose et al., 2011).

\section{Employee Performance}

Fernando and Dissanayake (2019) defined employee performance as how employees carry out the tasks assigned to them within stipulated deadlines. To improve value to consumers, reduce costs, and function effectively, organizations typically create performance goals for individual employees and the organization as a whole (Fidyah \& Setiawati, 2020; Inuwa, 2016; Kiruja \& Mukuru, 2018). Thus, performance relates to the efficacy, quality, and efficiency of a task for an individual employee. According to Pradhan (2016), employees' performance is more likely to be enhanced when they are allowed to participate in decision-making and contribute to the implementation of change that affects them. Employee performance is viewed as an ongoing process, and it is based on the quality of work, cost-effectiveness, punctuality, and response to one's task (Oparanman \& Nwaeke, 2015; Rashki et al., 2014).

\section{Hypothesis Formulation}

\section{Job Rotation Practices and Employees' Performance}

According to Fægri et al. (2010), job rotation enhances employees' problem-solving skills and warrants an understanding of their job holistically. Similarly, several studies reveal that rotating jobs is a beneficial operational approach for improving performance and productivity (Origo \& Pagani, 2008; Lebow et al., 2012; Sanséau \& Opoku, 2019). For instance, Oparanman and Nwaeke (2015) examined job rotation to predict employees' performances in business organizations. The data analysis reveals that job rotation influences the employees' job performances positively and significantly. Hence, the study recommended that for optimum performance of an organization, job rotation needs to be balanced with other factors such as job quality, employee attitude toward the job, time spent on the job, superior remuneration and motivation, and other related issues that affect employees.

Yavarzadeh et al. (2015) assessed the effect of job rotation on individual and organizational consequences. They found job rotation to be associated with three components of individual outcomes, including job alienation, job satisfaction, and job safety. While assessing the effects of job rotation on organizational consequences, the study finds a significant relationship between job rotation and four hypothesized components of organizational justice, organizational innovation, organizational learning, and organizational commitment. Similarly, Dhanraj and Parumasur (2014) examined employees' perceptions of job rotation on productivity and job security in the South African textile industry. The study revealed that employees perceive that job rotation has a high degree of positive impact on productivity, and job security, respectively.

Likewise, a study conducted by Bautista et al. (2017) to examine the effect of job rotation practices on employees' performance and job satisfaction level in accounting firms in Batangas, Philippines, revealed a positive level of agreement which proves that job rotation has a positive and significant relationship with both employee performance and job satisfaction in manufacturing firms in Batangas, Philippines. Therefore, by inference to the survey results, job rotation positively predicts employees' job performance significantly in manufacturing firms. 
Further, Taiwo et al. (2019) also examined the effect of job rotation on employees' performance in Nigeria regarding Skye Bank Nigeria Plc. The study revealed that job rotation significantly impacts performance through employee improvement and versatility. The finding of this study lends support to conclude that employees can improve their performance through job rotation. This is because job rotation makes employees more versatile and improves their ability to perform their jobs. A similar study by Tarus (2014) investigated the impact of job rotation strategy on the high-performance workplace in the Lake Victoria North Water Services Board in Kenya. The results of the SEM showed that job rotation significantly predicted a high-performance workplace. Finally, Nafei (2014) resonates with prior studies by highlighting the relevance of job rotation in enhancing employee horizons and empowerment, leading to increased performance and organizational effectiveness due to job satisfaction and skill diversity.

Contrary to the findings above, Hsieh and Chao (2004) conclude that for high-tech industry employees, the professionalism and specialization of jobs create more significant benefits than job rotation. Likewise, a study by Jocom et al. (2017) revealed that job rotation has an insignificant influence on employees' performance. Still, formal training does have a significant positive influence on the performance of employees. Similarly, Tsuma and Omondi (2015) recommended specialization as more effective than job rotation in improving employees' overall problem-solving skills and productivity. Therefore, in line with these arguments above, the study hypothesized that:

\section{$H_{1}:$ Job rotation positively and significantly predicts employee performance.}

\section{Job Satisfaction, Organizational Commitment, and Employees' Performance}

According to Nnadi (1997), job satisfaction can be defined as an individual's reaction, attitude, or perception of work, a composite of numerous interconnected factors. These factors include economic incentives, social incentives, business policy and administration, interpersonal interactions, working environment, achievement, recognition, work itself, responsibilities, and advancement. Kiruja and Mukuru (2018) agree with Nnadi's point of view, stating that job satisfaction is a person's attitude toward their work. Certain elements unique to the workplace influence this attitude, including the supervisor's style, work processes and policies, working conditions, and fringe benefits. It is clear from the previous definitions of job satisfaction that it is a function of an employee's attitude toward their employment. Job satisfaction is vital in achieving recognition, salary, promotion, and other goals that translate into an overall sense of contentment. It also induces a happy emotional state, which frequently leads to a favorable work attitude since satisfied employees are more likely to be creative, loyal, adaptable, and innovative.

Additionally, Kinicki and Kreitner (2007) posit that performance is higher when the employees are happy and satisfied. This study's finding implies that employees' performance is influenced positively when they are satisfied with the organization's job rotation practices. This indicates that when employees are satisfied with job rotation, they achieve organizational objectives. This is consistent with the study by Al-Ahmadi, (2009) on productivity, which showed that satisfied employees exhibit higher job performance and are less likely to quit than those who are not happy with their jobs. On the other hand, Porter and Steers (2013) opined that most of today's employees are prone to job dissatisfaction due to excessive competition among themselves; this creates undesirable defiance at work and hence, degenerates their performance. This assertion resonates with Aziri (2011), who emphasizes that the sagacity around job satisfaction is that a satisfied employee is a happy employee, and a happy employee is an active employee.

Furthermore, Rose et al. (2011) examined job satisfaction as an antecedent of work performance among Malaysian public service officials. They discovered that job satisfaction is positively linked to organizational commitment, learning, and work performance. In a similar vein, Raza et al. (2015) found a strong link between salespersons' performance and job satisfaction while analyzing the nexus between job satisfaction and the performance of salespersons using adaptive selling practices of organizations. 
Moreover, Vermeeren et al. (2014), in a study to examine the link between public organizational performance and human resource management practices, found job satisfaction as a credible mediating variable between HRM practices and organizational performance and positively associated with employee performance. This assertion is supported by Inuwa (2016), which depicts a significantly positive connection between job satisfaction and the performance of a university's non-teaching staff. Furthermore, prior studies (Fidyah, \& Setiawati, 2020; Ratnasari et al., 2019) have demonstrated that job satisfaction stands as an intervening variable between organizational culture and employee performance as well as other employee outcomes. Considering the arguments above, the study proposes that;

\section{$\mathrm{H}_{2}$ : Organizational commitment mediates the relationship between job rotation practices and employees' performance \\ $H_{3:}$ Job satisfaction mediates the relationship between job rotation practices and employees' performance}

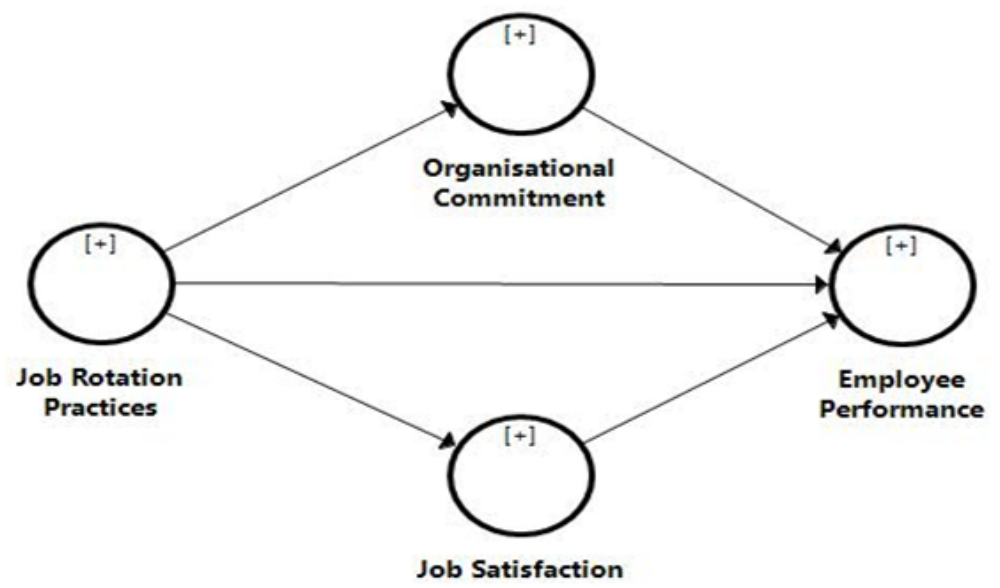

Figure 1: Proposed Model depicting Hypothesized Relationships

\section{Methodology}

\section{Research Design, Population, and Sample}

Using the descriptive survey design, this study's target population was the University of Education, Winneba (UEW) administrative staff. The administrative staff was considered appropriate for this study because they have been rotated routinely from one faculty, department, campus, section, or unit to another regularly or frequently. Thus, these administrators' job rotation experience levels can determine the accuracy of data obtained. Furthermore, to ensure inclusivity and diversity, both male and female administrators work as departmental administrative assistants and senior administrators at faculties or schools, departments, admissions units, examinations units, student records office, and other recognized offices within the University as of the second quarter 2021 were targeted. As per the $23^{\text {rd }}$ congregation report 2018 of the University of Education, Winneba, the University has a total administrative staff strength of 180, comprising 109 males and 71 female administrative staff (University of Education, Winneba Basic Statistics, 2018). Therefore, a sample size of one hundred and twenty-two (122) valid responses received was used for the current study. A sample size of one hundred (100) or more in a study like this has been considered sufficient and viable for further analysis by researchers (Sekaran \& Bougie, 2003; Bujang et al., 2018).

\section{Measurement Instrument}

Measurement scales were adopted from existing literature to ensure the validity and reliability of the instrument. Thus, job rotation practices, job satisfaction, and employee performance were measured with 4,8 , and 10 items developed by Saravani and Abbasi (2013). Sample items include "I have been moved from one official 
responsibility to another over the last few years or less" (Job Rotation Practices), "I am satisfied with the opportunities that come with job rotation" (Job Satisfaction) and "Task is accomplished at the required time" (Employee Performance), respectively. Organizational commitment (a composite of affective, continuance, and normative commitment) was also measured using a 9 item scale developed by Tsui et al. (1992), with a sample item "I feel my identity is linked with the identity of this organization". All responses were assessed on a 5-point Likert scale ranging from 1 (absolute disagreement) to 5 (absolute agreement).

\section{Results and Discussion}

Analysis and interpretations were made in two separate stages using the PLS-SEM approach. First, the model was measured by conducting a validity and reliability check on each model's constructs. Subsequently, the paths between the latent variables were estimated to test the structural model. Finally, the predictability of the study model and the constructs' level of significance were established to ensure that the measurements of all the constructs under study are valid and reliable to draw accurate conclusions (Matzler et al., 2013; Adu et al., 2020).

\section{Reliability and Validity}

The items' reliability was tested (as summarised in Table 1). The reliability test indicated that the individual items of the various constructs exceeded the minimum accepted level of 0.5 (Adu et al., 2020). The Cronbach's alpha test was used to assess the internal reliability and consistency among items. However, Hair et al. (2012) argue that using Cronbach's alpha to measure the reliability of internal consistency tends to provide a conservative measure in PLS-SEM. Henseler et al. (2015) followed this discussion by proposing composite reliability (CR) as a substitute. In exploratory research, CR coefficients from 0.61 to 0.70 are deemed sufficient, while coefficients above 0.70 are considered outstanding (Henseler et al., 2015). Table I shows that Cronbach's alpha and composite reliability coefficients are more significant than 0.6, indicating that the four reflective latent variables have high levels of internal consistency dependability. The Average Variance Extracted (AVE) of each latent variable was tested to see if it had convergent validity. Average Variance Extracted (AVE) results were higher than the 0.5 thresholds (Hair et al., 2012; Henseler et al., 2015).

Table 1: Factor Loadings, Cronbach's Alpha, Composite Reliabilities and Average Variance Extracted

\begin{tabular}{|c|c|c|c|c|c|}
\hline Latent Variable & Items & $\begin{array}{l}\text { Factor } \\
\text { Loadings }\end{array}$ & $\begin{array}{l}\text { Cronbach's } \\
\text { Alpha }\end{array}$ & $\begin{array}{l}\text { Composite } \\
\text { Reliability }\end{array}$ & $\begin{array}{l}\text { Average Variance } \\
\text { Extracted (AVE) }\end{array}$ \\
\hline Job Rotation & JRP1 & 0.747 & & & \\
\hline \multirow[t]{3}{*}{ Practices } & JRP2 & 0.674 & 0.757 & 0.754 & 0.521 \\
\hline & JRP3 & 0.647 & & & \\
\hline & JRP4 & 0.643 & & & \\
\hline Organizational & OC1 & 0.679 & & & \\
\hline \multirow[t]{8}{*}{ Commitment } & OC2 & 0.748 & & & \\
\hline & OC3 & 0.678 & 0.827 & 0.825 & 0.678 \\
\hline & OC4 & 0.652 & & & \\
\hline & OC5 & 0.679 & & & \\
\hline & OC6 & 0.645 & & & \\
\hline & OC7 & 0.659 & & & \\
\hline & OC8 & 0.634 & & & \\
\hline & OC9 & 0.654 & & & \\
\hline \multirow[t]{3}{*}{ Job Satisfaction } & JS1 & 0.697 & & & \\
\hline & JS2 & 0.664 & & & \\
\hline & JS3 & 0.732 & 0.734 & 0.730 & 0.575 \\
\hline
\end{tabular}




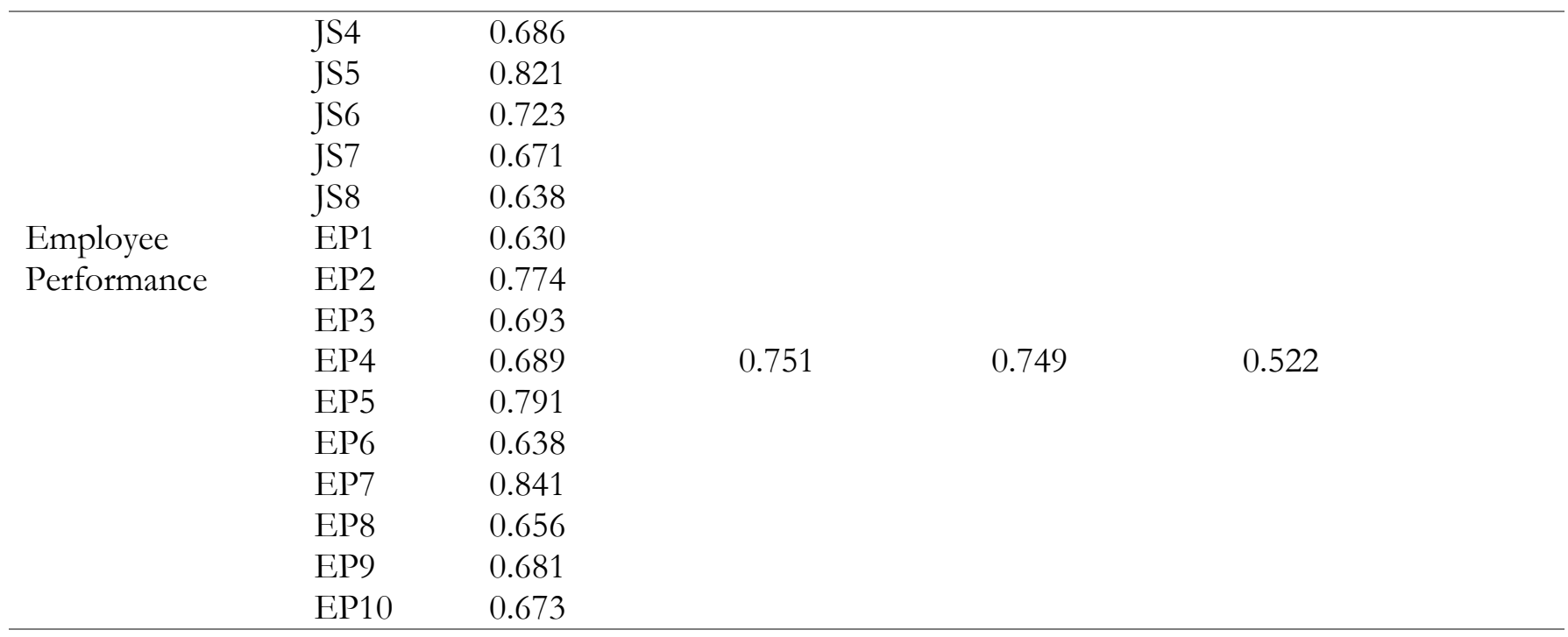

Source: Field Results (2021)

Subsequently, a correlation matrix was developed where all diagonal values representing the Average Variance Extracted square root were greater than the correlational coefficient of one construct to the other as recommended by Fornell and Larcker (1981) (as shown in Table 2). Similarly, Benitez et al. (2020) advanced that for a structural model to be well fitted, the values for the HTMT ratio should not exceed the usually considered stricter threshold of 0.85 or the considerable threshold of 0.90 or substantively less than 1 . From Table 2, the HTMT values are below the suggested threshold. This affirms discriminant validity in the study's dataset. Again, to ensure that the data was free of the variations in responses as a result of the instrument used rather than the basic predispositions of the respondents that the instrument sort of uncovering, the researcher tested for common method bias. According to Kock (2015), the presence of a variance inflation factor (VIF) greater than 3.3 is proposed as a sign of pathological collinearity and that the model may be contaminated by common method bias. It is evident from Table 2 that all the VIFs resulting from the collinearity test were less than the recommended threshold. Therefore, it can be concluded that the measurement model exhibited standard psychometric properties, and hence further analysis can be done.

Table 2: Square root of average extracted (AVE), variance inflation factor (VIF), and correlations among all constructs in the model.

\begin{tabular}{lllll}
\hline & JRP & OC & JS & EP \\
\hline JRP & $\underline{0.723}$ & & & \\
OC & 0.621 & $\underline{0.701}$ & $\underline{0.684}$ & \\
JS & 0.584 & 0.598 & $\underline{0.642}$ \\
EP & 0.672 & 0.677 & & \\
Hetrotrait-Monotrait & (HTMT) Ratio & & & \\
JRP & & & & \\
OC & 0.686 & 0.567 & 0.643 & \\
JS & 0.728 & 0.742 & & 1.234 \\
EP & 0.589 & & 2.342 & 1.353 \\
Common Method Bias & InnerVIF Values) & 1.734 & 1.829 & - \\
JRP & - & - & - & \\
OC & 1.721 & 1.884 & 2.524 & \\
JS & 1.323 & 1.341 & & \\
EP & 1.582 & & & \\
\hline
\end{tabular}

Job Rotation Practices-JRP, Organizational Commitment-OC, Job Satisfaction-JS, Employee Performance-EP. 


\section{Structural Path Significance in Bootstrapping}

The estimated values for path connections in the structural model were assessed and presented per the direction, extent, and significance as determined by the bootstrapping procedure, as shown in Figure 2 and Table 3. The paths from job rotation practices to organizational commitment and job satisfaction were significantly positive, i.e., $(\beta=0.114, \mathrm{t}=9.015, p<0.001)$ and $(\beta=0.046, \mathrm{t}=6.728, p<0.001)$ respectively. Likewise, the paths to employee performance from organizational commitment and job satisfaction were also significantly positive $(\beta=0.364, \mathrm{t}=9.106, p<0.001)$ and $(\beta=0.419, \mathrm{t}=4.610, p<0.001)$ respectively. Also, it was evident that the direct path from job rotation practices to employee performance was significant $(\beta=0.114$, $\mathrm{t}=4.984, p<0.001)$. These findings affirm the assertion made in $\mathrm{H} 1$.

The variation explained in each of the endogenous constructs, and the model's in-sample prediction accuracy was calculated using the $R^{2}$ values of all endogenous constructs. The $R^{2}$ values vary from 0 to 1 , with higher values indicating a higher level of predictive accuracy (Henseler et al., 2015). Thus, the $R^{2}$ values of 0.75 , 0.50 , and 0.25 , according to Hair et al. (2012), were deemed substantial, moderate, and weak, respectively. Per the results of this study, Job Rotation Practices explained $30.1 \%$ and $26.0 \%$ of the variance in Organizational Commitment and Job Satisfaction, respectively, based on the $R^{2}$ values. In quintessence, Job Rotation Practices moderately explain the variance in the mediating constructs. Furthermore, a combination of the predictor construct (Job Rotation Practices) and the two mediating constructs (Organizational Commitment and Job Satisfaction) explains $56.4 \%$ of the variance in the outcome construct (Employee Performance).

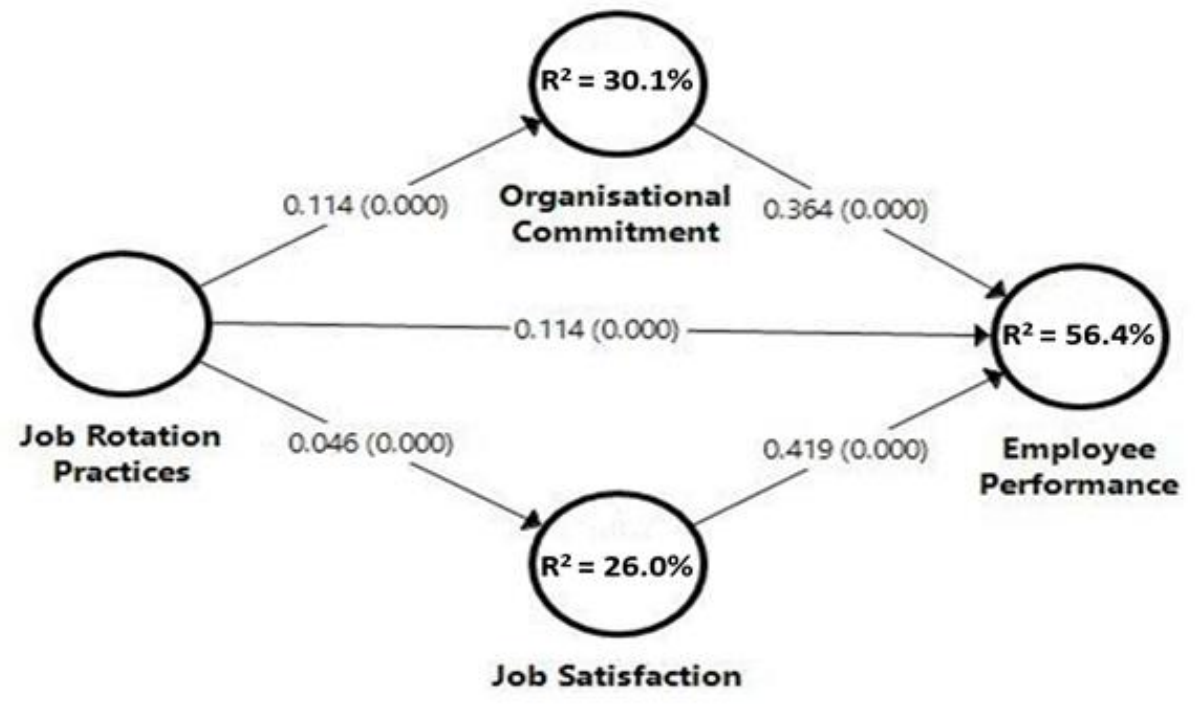

Figure 2: Relationships among Study V ariables

Table 3: Results of Partial Least Squares Path Analysis

\begin{tabular}{llllll}
\hline Path & $\begin{array}{l}\text { Original } \\
\text { Sample (O) }\end{array}$ & $\begin{array}{l}\text { Sample Mean } \\
(\mathbf{M})\end{array}$ & $\begin{array}{l}\text { Standard Deviation } \\
(\text { STDEV) }\end{array}$ & $\begin{array}{l}\text { T-Statistics } \\
(|\mathbf{O} / \mathbf{S T D E V}|)\end{array}$ & $\begin{array}{l}\mathbf{P} \\
\text { Values }\end{array}$ \\
\hline $\mathbf{J R P} \rightarrow \mathbf{O C}$ & 0.495 & 0.502 & 0.055 & 9.015 & 0.000 \\
$\mathbf{J R P} \rightarrow \mathbf{J S}$ & 0.427 & 0.431 & 0.063 & 6.728 & 0.000 \\
$\mathbf{J R P} \rightarrow \mathbf{E P}$ & 0.503 & 0.506 & 0.050 & 4.984 & 0.000 \\
$\mathbf{O C} \rightarrow \mathbf{E P}$ & 0.476 & 0.479 & 0.054 & 9.106 & 0.000 \\
$\mathbf{J S} \rightarrow \mathbf{E P}$ & 0.121 & 0.124 & 0.054 & 4.610 & 0.000 \\
\hline
\end{tabular}

Job Rotation Practices-JRP, Organizational Commitment-OC, Job Satisfaction-JS, Employee Performance-EP. 


\section{The Mediation Effects}

Table 4 illustrates the impacts of the intervening constructs (organizational commitment and job satisfaction) based on assessing the specific indirect effects of job rotation practices on employee performance. From the results, there exist significant specific indirect effects from job rotation practices to employee performance through Organizational Commitment (JRP $\rightarrow$ OC $\rightarrow$ EP: $\beta=0.169, p<0.001$ ) and Job Satisfaction $\mathrm{JRP} \rightarrow \mathrm{JS} \rightarrow \mathrm{EP}: \beta=0.171, \mathrm{p}<0.01)$. Hence, employees' organizational commitment and job satisfaction mediate the relationship between job rotation practices and performance, as stated in $\mathrm{H} 2$ and $\mathrm{H} 3$.

Table 4: The Mediation Effects (Specific Indirect Effects)

\begin{tabular}{llllllll}
\hline Path2 & $\begin{array}{l}\text { Original } \\
\text { Sample } \\
(\mathbf{O})\end{array}$ & $\begin{array}{l}\text { Sample } \\
\text { Mean } \\
\mathbf{( M )}\end{array}$ & $\begin{array}{l}\text { Standard } \\
\text { Deviation } \\
\text { (STDEV) }\end{array}$ & $\begin{array}{l}\text { T-Statistics } \\
(\mid \mathbf{O} / \text { STDEV } \mid)\end{array}$ & P Values & \\
\hline H2 & $\mathrm{JRP} \rightarrow \mathrm{OC} \rightarrow \mathrm{EP}$ & 0.169 & 0.168 & 0.042 & 4.022 & 0.000 & Mediation \\
H3 & $\mathrm{JRP} \rightarrow \mathrm{JS} \rightarrow \mathrm{EP}$ & 0.171 & 0.173 & 0.062 & 4.674 & 0.000 & Mediation \\
\hline
\end{tabular}

Job Rotation Practices-JRP, Organizational Commitment-OC, Job Satisfaction-JS, Employee Performance-EP.

The study sought to examine the impact of job rotation practices on administrative staff performance by determining how organizational commitment and job satisfaction mediates job rotation practices and employee performance. The findings of the current study suggest that job rotation practices significantly predicted employee performance, an indication that in an attempt to avoid repetition of tasks, public universities' management who resort to the rotation of administrators on the work would possibly reduce the monotonous nature of their work and increase employee performance. Similarly, the findings reveal a strong positive impact of job rotation practices on employee performance. The findings support that job rotation practices significantly predicted job satisfaction and organizational commitment. These findings are consistent with the earlier postulation that job rotation practices increase the chance of management to improve the performance of their employees (see Tarus, 2014; Dhanraj \& Parumasur, 2014; Oparanman \& Nwaeke, 2015). Further, Rashki et al. (2014) reported that job rotation practices are very efficient in reducing repetition strain injuries, thereby increasing employee performance, whiles Fægri et al. (2010) revealed that team efficiency is enhanced by job rotation. The evidence above is similar to our findings that job rotation practices effectively enhance employee performance.

Contrary to the current study's findings, Jocom et al. (2017) assert that, unlike job rotation, training significantly predicted employee performance much more than job rotation does. Likewise, Tsuma and Omondi (2015) recommended specialization as more effective than job rotation in improving employees' overall problem-solving skills and productivity. However, job rotation could be explained as a method used in training employees that have proven to be effective in improving the performance of individual employees at the workplace.

From Hertzberg's two-factor theory perspective, an organization that seeks to improve the motivating and hygiene factors would increase job satisfaction and reduce job dissatisfaction. In the current study, job rotation practices were seen as motivators as their improvement would result in job satisfaction, translating into improved employee performance. This suggests that any attempt to reduce repetitive work by rotating employees on the job would affect their level of satisfaction with the job. Consistent with Yavarzadeh et al., (2015) postulation that there is a significant link between job rotation and organizational justice, organizational innovation, organizational learning, and organizational commitment, the current study found that job rotation significantly predicted job satisfaction and organizational commitment. Also, Bautista et al. (2017) allude that job rotation positively and significantly affects employee performance and job satisfaction in manufacturing firms. Nafei (2014) found that job rotation helps enhance employee horizons and empowerment, leading to increased performance and organizational effectiveness due to job satisfaction and skill diversity. Job rotation 
practices, according to the findings of the current study, significantly influence the level of employees' job satisfaction and organizational commitment, which are not too different from prior studies (e.g., Origo \& Pagani, 2008; Ling et al., 2010), which mention that job satisfaction and organizational commitment could be improved through job rotation. More currently, Taiwo et al. (2019) found that job rotation significantly affects performance through employee improvement and versatility and on the job.

The study further found that employee performance could be enhanced when employees were satisfied and committed to the organization. Thus, job satisfaction and organizational commitment significantly predicted employee performance. These findings are suggestive that organizations' efforts to improve job satisfaction and organizational commitment through job rotation practices would improve the performance of their organizational members. Prior postulations support these findings that employees' performance could be improved through job rotation practices to increase employee's job satisfaction and organizational commitment (see Kinicki \& Kreitner, 2007; Ho, Chang, Shih \& Liang, 2009; Fidyah, \& Setiawati, 2020).

The mediation analysis found that job satisfaction and organizational commitment mediated the relationship between job rotation practices and employee performance. This indicates that employee performance would be improved by job rotation practices when employees perceive job satisfaction and are committed to the organization. This is consistent with the assertion that job rotation practices could result in job satisfaction and organizational commitment, translating into improved employee performance (Porter \& Steers 2013; Aziri 2011) by eliminating the undesirable attitudes created by job dissatisfaction. Raza et al. (2015) further opined that employee performance increases when satisfied with their jobs. Also, Vermeeren et al. (2014) found that job satisfaction is directly correlated with employee performance. Similarly, other researchers allude that job satisfaction arising from job rotation has a significant positive relationship with organizational commitment and employee performance of the non-academic staff of universities (Al- Ahmadi 2009; Inuwa 2016).

\section{Conclusion}

The purpose of the study was to propose and test a model to assess the impact of job rotation on employees' performance and examine the mediating effects of job satisfaction and organizational commitment in the nexus between job rotation and administrative staff performance. It was found that the direct prediction of employee performance by job rotation practices was weaker than the indirect prediction through job satisfaction. Given this, university management who seek to achieve higher performance must ensure that the job rotation practices they engaged in, satisfy the employees and provide the climate and opportunity for growth and career development, innovation, and creativity. The government and other policymakers should ensure that laws are being passed on ensuring fairness and equity in workload distributions to nurture employees to ensure the success of job rotation. Also, the leadership of universities should ensure that the job rotation exercise is well planned and systematic to equip employees with the relevant skills, training, and abilities to gain holistic insight into the organization. This will enhance the employees' problem-solving competencies and ultimately their performance.

It can also be concluded that job rotation practices have a much more positive impact on employees' performance when employees are committed to the organization. Thus, job rotation practices should improve employees' commitment to the organization in an attempt to induce an increased performance. Employees' satisfaction and commitment levels are significant for personal growth and development, as revealed by the study as partial mediators between job rotation practices and employee performance. Consequently, to achieve higher employee performance, management should induce the administrators by ensuring that employees are satisfied with the job rotation practices and committed to them. As revealed by the study, job satisfaction and organizational commitment will compel the employees' to develop the spirit of achieving higher performance. 
On the contrary, when employees are dissatisfied with the job rotation practices, they will be less likely to remain committed to the organization, adversely affecting how they will perform. As such, the human resource management of organizations must consider the level of satisfaction and the commitment levels of employees when implementing job rotation policies in organizations. This will go a long way to minimize the possible shortcomings of job rotation and ensure its maximum effectiveness.

\section{Implications for Practice and Future Studies}

The study's findings highlight the mediation effects of employees' level of job satisfaction and commitment in the relationship between job rotation and employees' performance and a weaker direct positive link between job rotation practices and employee performance. These findings imply that to induce employees to perform at their peak, the management of organizations must ensure that employees are satisfied and committed to the job rotation practices. Furthermore, as revealed by the study, job satisfaction and commitment will compel the employees' to develop the spirit of achieving higher performance and vice-versa.

Just like any other research work, this study is not exempted from limitations. For example, in the twenty-first century, businesses operate in a turbulent and ever-changing business environment characterized by intense competition, an unstable labor force, globalization, and quick changes in consumer demands. In line with this, job rotation as a creative problem-solving mechanism geared towards sharpening the skills and abilities to respond to these rapid changes quickly is required. Therefore, it is imperative to examine the impact of technology in facilitating adaptability and knowledge management across the generations in implementing the practice of job rotation. Again, the findings of this study were based on empirical evidence obtained from respondents from UEW. Perhaps the administrators may experience a unique and uniform job rotation system that may be different in other contexts; hence, the findings may not be enough to be generalized to cover other administrators in other universities who did not participate in the study. Thus, another study can be conducted to assess the mediation effects of the same constructs or other intervening variables in the relationship between job rotation and employees' performance in other universities or organizations elsewhere. Finally, this study employed Herzberg's hygiene-motivator theory, which is unilateral in considering job satisfaction. Therefore future studies can employ a pluralistic approach to study job rotation in universities or institutions in another context.

Funding: This research received no external funding.

Acknowledgments: We acknowledge there was no external funding support; all authors contributed accordingly in every part of the paper.

Conflicts of Interest: The authors declare no conflict of interest.

\section{References}

Adu, I. N., Boakye, K. O., Suleman, A. R., \& Bingab, B. B. B. (2020). Exploring the factors that mediate the relationship between entrepreneurial education and entrepreneurial intentions among undergraduate students in Ghana. Asia Pacific Journal of Innovation and Entrepreneurship, 14(2), 215-228.

Ajusa, M. R. K., \& Atambo, W. N. (2016). Influence of Job Rotation on Organizational Productivity: A Case of Mount Kenya University. Imperial Journal of Interdisciplinary Research, 2(10), 1358-1395.

Akhbari, M, Zargarani SH (2011). Reducing job burnout in Rang Pars Khodro using job rotation method, Third Specialized and Engineering Congress of Industries, Industries Department of Tehran Islamic Azad University. South Branch Studies on Improvement and Upheaval Management, 31(33), 233-248.

Al-Ahmadi, H. (2009). Factors affecting performance of hospital nurses in Riyadh Region, Saudi Arabia. International journal of health care quality assurance, 22(1), 40-54.

Allen, N. J., \& Meyer, J. P. (1996). Affective, continuance, and normative commitment to the organisation: An examination of construct validity. Journal of Vocational Behavior, 49(3), 252-276. 
Arasanmi, C. N., \& Krishna, A. (2019). Employer branding: perceived organizational support and employee retention-the mediating role of organizational commitment. Industrial and Commercial Training, 51(3), 174-183.

Aziri, B. (2011). Job satisfaction: A literature review. Management Research \& Practice, 3(4), 77-86.

Benitez, J., Henseler, J., Castillo, A., \& Schuberth, F. (2020). How to perform and report an impactful analysis using partial least squares: Guidelines for confirmatory and explanatory IS research. Information \& Management, 57(2), 103-168.

Bujang, M. A., Sa'at, N., \& Bakar, T. M. I. T. A. (2018). Sample size guidelines for logistic regression from observational studies with large population: emphasis on the accuracy between statistics and parameters based on real life clinical data. The Malaysian journal of medical sciences: MJMS, 25(4), 122.

Cansoy, R. (2019). The Relationship between School Principals' Leadership Behaviours and Teachers' Job Satisfaction: A Systematic Review. International Education Studies, 12(1), 37-52.

Dhanraj, D., \& Parumasur, S. B. (2014). Perceptions of the impact of Job Rotation on Employees, Productivity, The Organization and on Job Security. Corporate Ownership \& Control, 11(4), 682690.

Dilig-Ruiz, A., MacDonald, I., Varin, M. D., Vandyk, A., Graham, I. D., \& Squires, J. E. (2018). Job satisfaction among critical care nurses: A systematic review. International journal of nursing studies, 88, 123-134.

Fægri, T.E., Dybå, T. \& Dingsøyr, T. (2010). Introducing knowledge redundancy practice in software development: Experiences with job rotation in support work. Information and Software Technology, $5(2), \quad 1118-1132$.

Fernando, A. G. N. K., \& Dissanayake, D. M. R. S. (2019). The Effect of Job Rotation Practices on Employee Job Performance; Mediating Role of Intrinsic Motivation (with Special Reference to the

Private Commercial Banks in Sri Lanka). International Journal of Engineering and Management Research, 9(5), 27-31.

Fidyah, D. N., \& Setiawati, T. (2020). Influence of Organizational Culture and Employee Engagement on Employee Performance: Job Satisfaction as Intervening Variable. Review of Integrative Business and Economics Research, 9(4), 64-81.

Fornell, C., \& Larcker, D. F. (1981). Structural equation models with unobservable variables and measurement error: Algebra and statistics. Journal of marketing research, 18(3), 382-388.

Fried, A., \& Langer, S. (2020). Typology of Organizational deviance from standards. Understanding Deviance in a World of Standards, 3(2), 48-96.

Hair, J. F., Sarstedt, M., Pieper, T. M., \& Ringle, C. M. (2012). The use of partial least squares structural equation modelling in strategic management research: a review of past practices and recommendations for future applications. Long range planning, 45(6), 320-340.

Halcomb, E., Smyth, E., \& McInnes, S. (2018). Job satisfaction and career intentions of registered nurses in primary health care: an integrative review. BMC Family Practice, 19(1), 1-14.

Harvey, G., Williams, K., \& Probert, J. (2013). Greening the airline pilot: HRM and the green performance of airlines in the UK. The International Journal of Human Resource Management, 24(1), 152-166.

Henseler, J., Ringle, C. M., \& Sarstedt, M. (2015). A new criterion for assessing discriminant validity in variance-based structural equation modelling. Journal of the academy of marketing science, 43(1), 115135.

Herzberg, F. W., Mausner, B. \& Snyderman, B. (1957). The Motivation to Work, Wiley, New York.

Herzberg, F., Mausner, B. and Synderman, B.S. (1959). The Motivation to Work, 2nd edition. New York: John Wiley and Sons.

Herzberg, F.I. (1966). Work and the nature of man. Oxford, England: World.

Ho, W. H., Chang, C. S., Shih, Y. L., \& Liang, R. D. (2009). Effects of job rotation and role stress among nurses on job satisfaction and organizational commitment. BMC Health Services Research, 9(1), 8-19. 
Hsieh, A., \& Chao, H. (2004). A Reassessment of the Relationship between Job Specialisations, Job Rotation and Job Burnout: The International Journal of Human Resource Management, 15(6), 1108-1123.

Inuwa, M. (2016). Job satisfaction and employee performance: An empirical approach. The Millennium University Journal, 1(1), 90-103.

Jocom, J., Lambey, L., \& Pandowo, M. (2017). The Effect of Job Rotation and Training on Employee Performance in PT. Pegadaian (Persero) Manado. Journal EMBA: Journal Riset Ekonomi, Manajemen, Bisnis dan Akuntansi, 5(2), 279-288.

Kinicki, A. and Kreitner, R. (2007). Organizational Behavior. New York, NY: McGraw-Hill.

Kiruja, E. K., \& Mukuru, E. (2018). Effect of motivation on employee performance in public middle level Technical Training Institutions in Kenya. International Journal of Advances in Management and Economics, 2(4), 22-33.

Lambert, E. G., Paoline III, E. A., \& Hogan, N. L. (2020). The Effects of Inmate Medical Issues on Correctional Staff Job Involvement and Organizational Commitment. Journal of Correctional Health Care, 26(1), 66-82. https://doi.org/1078345819897609.

Lebow, J. L., Chambers, A. L., Christensen, A., \& Johnson, S. M. (2012). Research on the treatment of couple distress. Journal of Marital and Family therapy, 38(1), 145-168.

Ling, K. C., Chai, L. T., \& Piew, T. H. (2010). The 'Inside-out 'and 'Outside-in' Approaches on Students' Perceived job rotation: An Empirical Evaluation. Management Science and Engineering, 4(2), 1-13

Locke, E.A. (1976). The Nature and Causes of Job Satisfaction. In: Dunnette, M.D., Ed., Handbook of Industrial and Organizational Psychology, 1(1), 1297-1343.

Mangundjaya, W. L., \& Farahzehan, E. R. (2019). Change Communication and Organizational Trust on Employee's Commitment to Change, 52(6), 671-692.

Matzler, K., Bailom, F., von den Eichen, S. F., \& Kohler, T. (2013). Business model innovation: coffee triumphs for Nespresso. Journal of Business Strategy, 34(2), 30-37

Mohan, K., \& Gomathi, S. (2015). The effects of job rotation practices on employee development: An empirical study on nurses in the hospitals of vellore district. Mediterranean Journal of Social Sciences, 6(1), 209-209.

Mohsan, F., Nawaz, M. M., \& Khan, M. S. (2012). Impact of job rotation on employee motivation, commitment and job involvement in banking sector of Pakistan. African Journal of Business Management, 6(24), 7114- 7119.

Nafei, W.A. (2014). Do job rotation and role stress affect job attitudes? A study from Egyptian context. American International Journal of Social Science, 3(1), 94-108.

Nnadi, E. E. (Ed.). (1997). Handbook on human resources management for healthcare professionals. Howard University Press.

Nyuur, R. B., Ofori, D. F., \& Debrah, Y. A. (2016). The impact of FDI inflow on domestic firms' uptake of CSR activities: The moderating effects of host institutions. Thunderbird International Business Review, 58(2), 147-159.

Oparanman, A.O. \& Nwaeke, L. I. (2015). Impacts of job rotations and employees' performances in manufacturing companies: Nigeria. Journal of Economics, Management and Trade, 7(3), 183-187.

Origo, R. \& Pagani, L. (2008). Workplace flexibility and job satisfaction: Some evidence from Europe. International Journal of Manpower, 29(1), 42-48.

Porter, L. W., \& Steers, R. M. (2013). Employee organisation linkages: The psychology of commitment, absenteeism, and turnover. Academic press.

Rashki, Z., Hasanqasemi, A. \& Mazidi, A. (2014). The study of job rotation and staff performance in customs organisation of Golestan and Mazandaran Provinces. Kuwait Chapter of Arabian Journal of Business and Management Review, 3(7), 186-194.

Ratnasari, S. L., Sutjahjo, G., \& Adam, A. (2019, April). Impact of Organizational Culture and Organizational Commitment to Employee Performance through Job Satisfaction in Digital Era. In 2nd Padang 
International Conference on Education, Economics, Business and Accounting (PICEEBA-2 2018). Atlantis Press.

Raza, M. Y., Rafique, T., Hussain, M. M., Ali, H., Mohsin, M., \& Shah, T. S. (2015). The impact of working relationship quality on job satisfaction and sales person performance: An adaptive selling behaviour. Asia-Pacific Journal of Management Research and Innovation, 11(1), 1-8.

Redditt, J., Gregory, A. M., \& Ro, H. (2019). An examination of organizational commitment and intention to stay in the timeshare industry: variations across generations in the workplace. International Journal of Hospitality \& Tourism Administration, 20(2), 206-225.

Rose, R. C., Kumar, N., \& Pak, O. G. (2011). The effect of organizational learning on organizational commitment, job satisfaction and work performance. Journal of Applied Business Research (JABR), 25(6), 55-66.

Sanséau, P. Y., \& Opoku, F. K. (2019). Perception of pay equity in Public Universities in Ghana: Effect on individual performance and work behaviour. International Journal of Public Administration, 42(1), 7685.

Saravani, S. R., \& Abbasi, B. (2013). Investigating the influence of job rotation on performance by considering skill variation and job satisfaction of bank employees. Tehnicki vjesnik, 20(3), 473-478.

Sebt, V., \& Ghasemi, S. S. (2021). Presenting a Comprehensive Smart Model of Job Rotation as a Corporate Social Responsibility to Improve Human Capital. International Journal of Supply and Operations Management, 8(2), 212-231.

Sekaran, U., \& Bougie, R. (2003). Research Methods For Business, A Skill Building Approach, John Willey \& Sons. Inc. New York.

Taiwo, O., Olalekan, E, \& Abiodun, O. E. (2019). Effects of job rotation on employees' Performance in Nigerian Banks. International Journal of Economics, Commerce and Management, 7(2), 495-502.

Tarus, B. K. (2014). Effects of Job Rotation Strategy on High Performance Workplace, in Lake Victoria North Water Services Board, Kenya. International Journal of Business and Management, 9(11), 139147.

Thakur, M. B., Vetal, J. B., \& Bhatt, L. (2020). The relationship between Organizational Commitment and Job satisfaction. Our Heritage, 68(1), 1220-1229.

Thongpapanl, N., Kaciak, E., \& Welsh, D. H. (2018). Growing and aging of entrepreneurial firms: Implications for job rotation and joint reward. International Journal of Entrepreneurial Behavior \& Research, 24(6), 1087- 1103.

Tsui, A., Egan, T. \& O’Reilly, C. (1992). 'Being different: Relational demography and organizational attachment', Administrative Science Quarterly, 37(1), 549-588.

Tsuma, J. \& Omondi, M. (2015). Effect of job design on employee satisfaction levels in private universities in Kenya. The Strategic Journal of Business and Change Management, 2(92), 1314-1340.

Vermeeren, B., Kuipers, B., \& Steijn, B. (2014). Does leadership style make a difference? Linking HRM, job satisfaction, and organizational performance. Review of Public Personnel Administration, 34(2), 174195.

Yavarzadeh, M.R., Rabie, A., \& Hoseini, M. (2015). Assessing the Effect of Job Rotation on Individual and Organizational Consequences Case Study: Isfahan State Welfare Organization. Global Advanced Research Journal of Management and Business Studies, 4(9), 449-452.

Zin, M., Mohd, L., \& Ibrahim, H. (2021). The Moderating Effect of Organization Tenure on Job Rotation and Career Development. Annals of Contemporary Developments in Management \& HR (ACDMHR), 3(3), 1-9. 